\title{
Identification of Causes of Conflicts and Disputes in Construction Industry
}

\author{
L.Madhumitha, A.Sivakumar, G.Dhanasekar, P.Karthikeyan
}

\begin{abstract}
In construction industry number of participants from various professions having with different levels of knowledge and talents are involved and the conflicts are unavoidable. Conflicts and disputes are the major factor that will lead the projects to be unsuccessful. Thus it is necessary to identify the causes of conflicts and disputes to complete the project on estimated time, budget and quality. The main aim of the project is to identify and analyze the main causes of conflicts and disputes in construction projects. In order to attain the aim, a literature review was conducted to identify the factors causing conflicts and disputes. The factors identified were categorized into eight and the main causes of conflicts and disputes were determined. Finally analysis were conducted to rank the major factors causing conflicts and disputes in construction industry.
\end{abstract}

Keywords: Conflicts, Disputes, Literature review, Factors, Construction industry.

\section{INTRODUCTION}

Throughout the world, dispute is unavoidable in the construction field. A dispute was defined as situation where two parties differ in the assertion of a contractual right. The causes are abundant mainly occurred by what happened on site between the parties. All the project management team are challenged by the risk of dispute from the initiating to the closing stage of a project (Wantong Zhao, 2019). Conflicts have to manage as soon as possible or else they rapidly turn into disputes. Dispute is one of the crucial factor which inhibit magnificently accomplishment of any project. Hence it is necessary to be attentive of the sources of conflicts and disputes to complete project within the estimated time, quality and budget (Sagar sony et al., 2017). Based upon the identification of the sources responsible for conflicts we can deal more effectively and efficiently to these problems (Acharya et al., 2006). Conflicts are such situation of occurrence of the discrepancy between the values or aims to be achieved, both in the individual and in relationship to others (Anita Rauzana, 2016). Naturally, if the events can't reach a resolution themselves, high-priced, time-consuming felony techniques begin, which severly affects the participants. Disputes are facts in all over the construction industry.

Revised Manuscript Received on February 05, 2020.

* Correspondence Author

Ms.L.Madhumitha, M.E Construction Engineering and Management, Department of Civil Engineering, Kongu Engineering College, Erode, Tamilnadu, India.

Mr.A.Sivakumar, Assistant Professor, Kongu Engineering College, Erode, Tamilnadu,

Mr.G.Dhanasekar, M.E Construction Engineering and Management, Department of Civil Engineering, Kongu Engineering College, Erode, Tamilnadu, India.

Dr.P.Karthikeyan, Assistant Professor, Kongu Engineering College, Erode, Tamilnadu

(C) The Authors. Published by Blue Eyes Intelligence Engineering and Sciences Publication (BEIESP). This is an open access article under the CC BY-NC-ND license (http://creativecommons.org/licenses/by-nc-nd/4.0/)
Without any method to address them at the early stage, minor issues can fester and develop, with crippling result for task members. Waiting till the end to deal with dispute inevitably makes it tougher and extra expensive to resolve. Parties involved in a certain disputes, or indeed any industrial disputes, typically opt to maintain manage over the outcome and preserve a working business (Shaikh SK Sameer et al., 2016).

\section{RESEARCH METHODOLOGY}

To identify the causes of conflicts and disputes in construction industry, the following methodology is followed based on the literature review and questionnaire survey was conducted to ensure the robust methodological design.

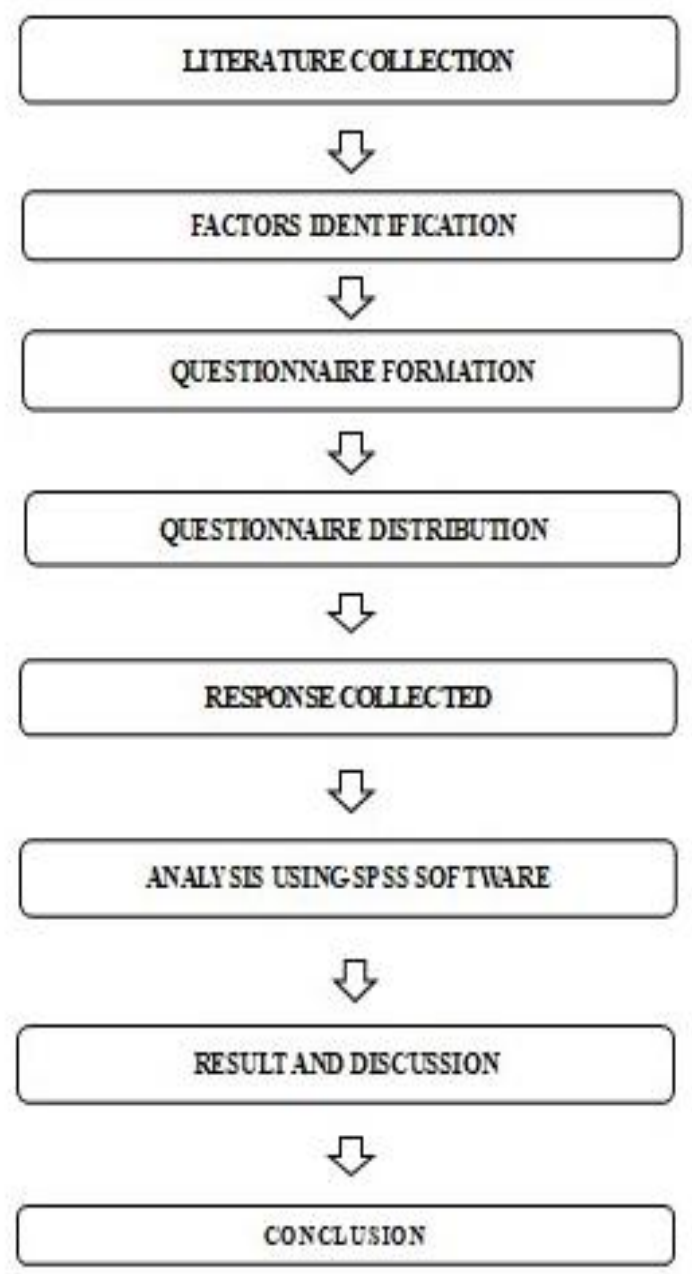

Fig 1. Methodology

Published By:

Blue Eyes Intelligence Engineering DOI: 10.35940/ijeat.C5154.029320 


\section{Identification of Causes of Conflicts and Disputes in Construction Industry}

\section{FACTOR IDENTIFICATION}

There are some factors which influence conflicts and disputes in the construction industry. These factors were identified based on literature study.

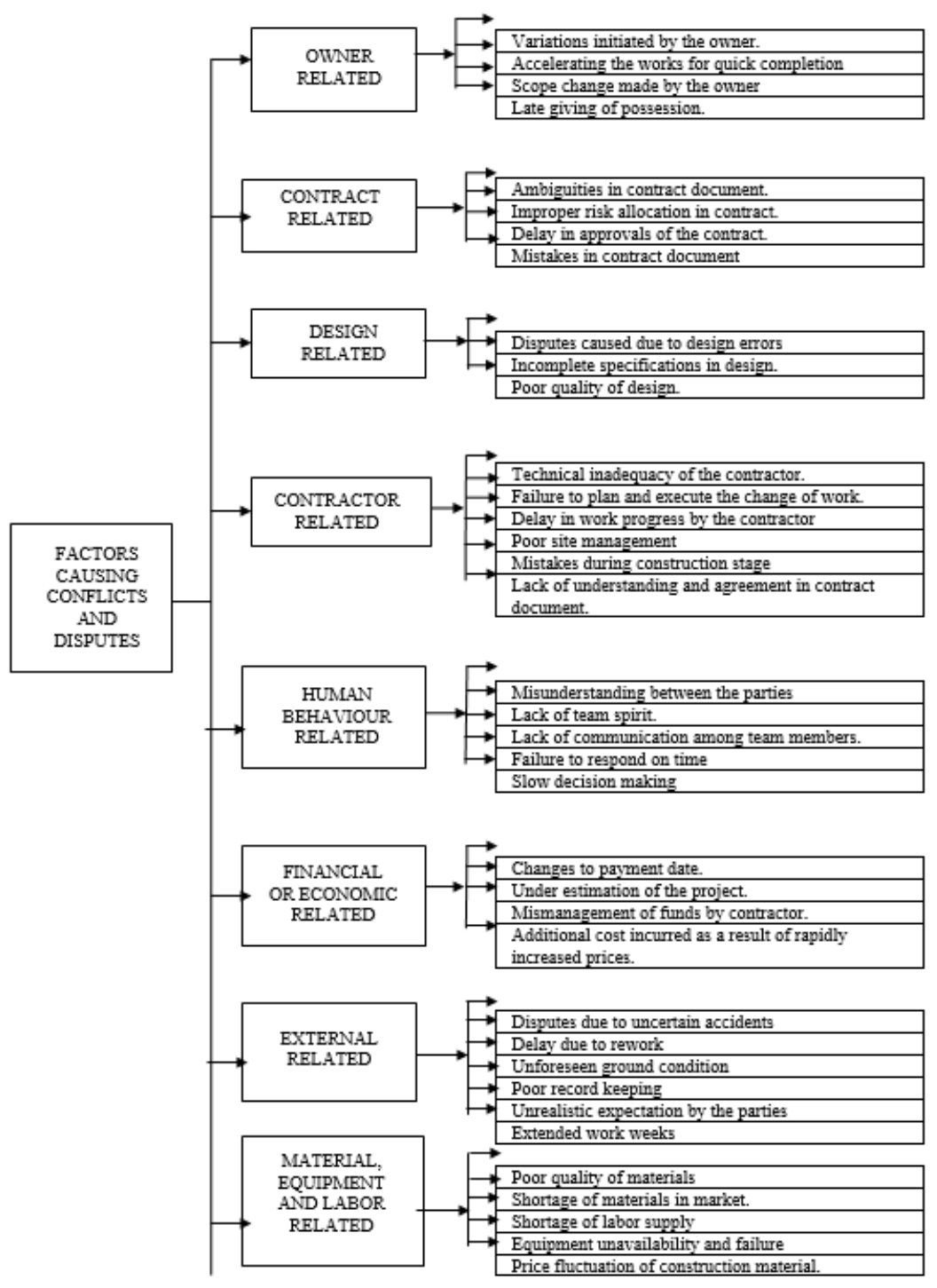

Fig. 2 Factors causing conflicts and disputes

Table No: 1. Causes of Conflicts and Disputes

\begin{tabular}{|c|c|c|c|}
\hline S.NO & FACTORS & SUB FACTORS & RESEARCHES \\
\hline \multirow{3}{*}{1} & \multirow{3}{*}{ OWNER RELATED } & $\begin{array}{l}\text { Variations initiated by the } \\
\text { owner. }\end{array}$ & $\begin{array}{l}\text { Charlie Woodley(2019), } \\
\text { Essan K. Zaneldin (2018), Malek Mishmish et al.,(2018), Emre CakmaK et } \\
\text { al.,(2014), C. Bvumbwe et al.,(2011), Kumaraswamy, M.M(1997) }\end{array}$ \\
\hline & & $\begin{array}{l}\text { Accelerating the work for } \\
\text { quick completion. }\end{array}$ & $\begin{array}{l}\text { Essan K. Zaneldin (2018), Malek Mishmish et al.,(2018), Dimitrios Robert et } \\
\text { al.,(2018), Nirmal Kumar Acharya et al.,(2016), Kumaraswamy, M.M(1997) }\end{array}$ \\
\hline & & $\begin{array}{l}\text { Delay in payment for } \\
\text { cumulative works. }\end{array}$ & $\begin{array}{l}\text { Essan K. Zaneldin (2018), Malek Mishmish et al.,(2018), Sagar soni et al., } \\
\text { (2017), Nirmal Kumar Acharya et al.,(2016), Nirmal Kumar Acharya et } \\
\text { al.,(2016), Enshassi et al.,(2014) }\end{array}$ \\
\hline
\end{tabular}




\begin{tabular}{|c|c|c|c|}
\hline & & $\begin{array}{l}\text { Scope change made by the } \\
\text { owner }\end{array}$ & $\begin{array}{l}\text { Charlie Woodley (2019), Essan K. Zaneldin (2018), Malek Mishmish et } \\
\text { al.,(2018), Dimitrios Robert et al.,(2018), Nirmal Kumar Acharya et } \\
\text { al.,(2016), Sepani Senaratne et al.,(2014) }\end{array}$ \\
\hline & & Late giving of possession. & $\begin{array}{l}\text { Malek Mishmish et al.,(2018) Nirmal Kumar Acharya et al.,(2016), } \\
\text { Kumaraswamy, M.M(1997) }\end{array}$ \\
\hline \multirow{4}{*}{2} & \multirow{4}{*}{ CONTRACT RELATED } & $\begin{array}{l}\text { Ambiguities in contract } \\
\text { document. }\end{array}$ & $\begin{array}{l}\text { Essan K. Zaneldin (2018), Malek Mishmish et al.,(2018), Dimitrios Robert et } \\
\text { al.,(2018), Sagar soni et al., (2017), Anita Rauzana(2016), Nirmal Kumar } \\
\text { Acharya et al.,(2016), Nency Dangrochiya et al.,(2006), Kumaraswamy, } \\
\text { M.M(1997) }\end{array}$ \\
\hline & & $\begin{array}{l}\text { Improper risk allocation in } \\
\text { contract. }\end{array}$ & $\begin{array}{l}\text { Essan K. Zaneldin (2018), Nirmal Kumar Acharya et al.,(2016), } \\
\text { Kumaraswamy, M.M(1997) }\end{array}$ \\
\hline & & $\begin{array}{l}\text { Delay in approvals of the } \\
\text { contract. }\end{array}$ & Malek Mishmish et al.,(2018), Emre CakmaK et al.,(2014) \\
\hline & & $\begin{array}{l}\text { Mistakes in contract } \\
\text { document }\end{array}$ & Sagar soni et al., (2017), Emre CakmaK et al.,(2014) \\
\hline \multirow{3}{*}{3} & & $\begin{array}{l}\text { Disputes caused due to } \\
\text { design errors }\end{array}$ & $\begin{array}{l}\text { Charlie Woodley (2019), Essan K. Zaneldin (2018), Anita Rauzana(2016), } \\
\text { Nirmal Kumar Acharya et al.,(2016), Nirmal Kumar Acharya et al.,(2016), } \\
\text { Nency Dangrochiya et al.,(2006), Kumaraswamy, M.M(1997) }\end{array}$ \\
\hline & \multirow[t]{2}{*}{ DESIGN RELATED } & $\begin{array}{l}\text { Incomplete specifications in } \\
\text { design. }\end{array}$ & $\begin{array}{l}\text { Essan K. Zaneldin (2018), Malek Mishmish et al.,(2018), Anita } \\
\text { Rauzana(2016), Nirmal Kumar Acharya et al.,(2016), Sepani Senaratne et } \\
\text { al.,(2014), Nency Dangrochiya et al.,(2006) }\end{array}$ \\
\hline & & Poor quality of design. & Nirmal Kumar Acharya et al.,(2016) \\
\hline \multirow{6}{*}{4} & \multirow{6}{*}{$\begin{array}{l}\text { CONTRACTOR } \\
\text { RELATED }\end{array}$} & $\begin{array}{l}\text { Technical inadequacy of the } \\
\text { contractor. }\end{array}$ & $\begin{array}{l}\text { Malek Mishmish et al.,(2018), Sagar soni et al., (2017), Nirmal Kumar } \\
\text { Acharya et al.,(2016) }\end{array}$ \\
\hline & & $\begin{array}{l}\text { Failure to plan and execute } \\
\text { the change of work. }\end{array}$ & $\begin{array}{l}\text { Malek Mishmish et al.,(2018), Anita Rauzana(2016), Nirmal Kumar } \\
\text { Acharya et al.,(2016) }\end{array}$ \\
\hline & & $\begin{array}{l}\text { Delay in work progress by } \\
\text { the contractor }\end{array}$ & Malek Mishmish et al.,(2018), Nirmal Kumar Acharya et al.,(2016) \\
\hline & & Poor site management & Malek Mishmish et al.,(2018), Anita Rauzana(2016) \\
\hline & & $\begin{array}{l}\text { Mistakes during } \\
\text { construction stage }\end{array}$ & Dimitrios Robert et al.,(2018) \\
\hline & & $\begin{array}{l}\text { Lack of understanding and } \\
\text { agreement in contract } \\
\text { document. }\end{array}$ & Anita Rauzana(2016) \\
\hline \multirow{5}{*}{5} & \multirow{5}{*}{$\begin{array}{l}\text { HUMAN BEHAVIOUR } \\
\text { RELATED }\end{array}$} & $\begin{array}{l}\text { Misunderstanding between } \\
\text { the parties }\end{array}$ & Sagar soni et al., (2017), Nency Dangrochiya et al.,(2006) \\
\hline & & Lack of team spirit. & $\begin{array}{l}\text { Sagar soni et al., (2017), Nirmal Kumar Acharya et al.,(2016), Nency } \\
\text { Dangrochiya et al.,(2006) }\end{array}$ \\
\hline & & $\begin{array}{l}\text { Lack of communication } \\
\text { among team members. }\end{array}$ & $\begin{array}{l}\text { Charlie Woodley(2019), Sagar soni et al., (2017), Anita Rauzana(2016), } \\
\text { Nirmal Kumar Acharya et al.,(2016), Sepani Senaratne et al.,(2014), Nency } \\
\text { Dangrochiya et al.,(2006), Kumaraswamy, M.M(1997) }\end{array}$ \\
\hline & & Failure to respond on time & Anita Rauzana(2016) \\
\hline & & Slow decision making & $\begin{array}{l}\text { Charlie Woodley(2019), Essan K. Zaneldin (2018), Nirmal Kumar Acharya } \\
\text { et al.,(2016), Enshassi et al.,(2014) }\end{array}$ \\
\hline \multirow{4}{*}{6} & \multirow{4}{*}{$\begin{array}{l}\text { FINANCIAL / } \\
\text { ECONOMICAL } \\
\text { RELATED }\end{array}$} & Changes to payment date. & Nirmal Kumar Acharya et al.,(2016) \\
\hline & & $\begin{array}{l}\text { Under estimation of the } \\
\text { project. }\end{array}$ & $\begin{array}{l}\text { Essan K. Zaneldin (2018), Malek Mishmish et al.,(2018), Anita } \\
\text { Rauzana(2016), C. Bvumbwe et al.,(2011), Enshassi et al.,(2014) }\end{array}$ \\
\hline & & $\begin{array}{l}\text { Mismanagement of funds by } \\
\text { contractor. }\end{array}$ & C. Bvumbwe et al.,(2011) \\
\hline & & $\begin{array}{l}\text { Additional cost incurred as a } \\
\text { result of rapidly increased } \\
\text { prices. }\end{array}$ & Essan K. Zaneldin (2018), Enshassi et al.,(2014) \\
\hline \multirow{6}{*}{7} & \multirow{6}{*}{ EXTERNAL FACTORS } & $\begin{array}{l}\text { Disputes due to uncertain } \\
\text { accidents. }\end{array}$ & $\begin{array}{l}\text { Malek Mishmish et al.,(2018), Vahidreza et al.,(2016), Nirmal Kumar } \\
\text { Acharya et al.,(2016), K. C. Iyer et al.,(2008) }\end{array}$ \\
\hline & & Delay due to rework. & Essan K. Zaneldin (2018) \\
\hline & & $\begin{array}{l}\text { Unforeseen ground } \\
\text { condition of the project. }\end{array}$ & $\begin{array}{l}\text { Essan K. Zaneldin (2018), Malek Mishmish et al.,(2018), K. C. Iyer et } \\
\text { al.,(2008) }\end{array}$ \\
\hline & & Poor record maintenance. & Vahidreza et al.,(2016), C. Bvumbwe et al.,(2011) \\
\hline & & $\begin{array}{l}\text { Unrealistic expectation by } \\
\text { the contractor. }\end{array}$ & $\begin{array}{l}\text { Sagar soni et al., (2017), Vahidreza et al.,(2016), Nency Dangrochiya et } \\
\text { al.,(2006) }\end{array}$ \\
\hline & & Extended work weeks. & $\begin{array}{l}\text { Charlie Woodley(2019), Malek Mishmish et al.,(2018), Dimitrios Robert et } \\
\text { al.,(2018) }\end{array}$ \\
\hline \multirow{5}{*}{8} & \multirow{5}{*}{$\begin{array}{l}\text { MATERIAL, LABOR } \\
\text { AND EQUIPMENT } \\
\text { RELATED }\end{array}$} & Poor quality of materials. & Nency Dangrochiya et al.,(2006), Enshassi et al.,(2014) \\
\hline & & $\begin{array}{l}\text { Shortage of materials in } \\
\text { market. }\end{array}$ & Nirmal Kumar Acharya et al.,(2016) \\
\hline & & Shortage of labor supply & Nirmal Kumar Acharya et al.,(2016) \\
\hline & & $\begin{array}{l}\text { Equipment unavailability } \\
\text { and failure }\end{array}$ & Nirmal Kumar Acharya et al.,(2016) \\
\hline & & $\begin{array}{l}\text { Price fluctuation of } \\
\text { construction material. }\end{array}$ & $\begin{array}{l}\text { Essan K. Zaneldin (2018), Dimitrios Robert et al.,(2018), Enshassi et } \\
\text { al.,(2014) }\end{array}$ \\
\hline
\end{tabular}

\section{QUESTIONNAIRE DETAIL}

Questionnaire has been formulated with the identified factors taken from both the literatures and direct inspection. Questionnaire should be such that it is simple to read and understand. Also the questionnaire was framed as per Lekert scales running from not at all, to less extent, marginally, to certain extent, substantially.

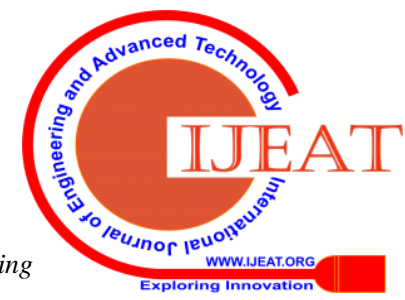




\section{Identification of Causes of Conflicts and Disputes in Construction Industry}

These five positions were given weights of 1, 2, 3, 4 and 5 for scoring purposes. Questionnaire consists of two sections, first section consists of respondent's demographic profile and the second section consists the set of questions based on the factors contributing to the performance of an employee. It requires the respondents to indicate the degree of agreement with each of a serious of statement related to the stimulus objects. This type of question is easy to construct and administer. Respondents readily understand how to use the scale. Questionnaire development is an effective data collection method to measure the adaptable of importance.

\section{DATA COLLECTION}

A total 37 questionnaires were framed to identify the causes of disputes and conflicts in the construction industry. Totally 75 number of question were distributed and out of those 72 responses has been received. The response rate will be explained in following table and chart.

Table No: 2. Response rate

\begin{tabular}{|c|c|}
\hline DESCRIPTION & RESPONSE RATE \\
\hline $\begin{array}{c}\text { Number of questions } \\
\text { distributed }\end{array}$ & 75 \\
\hline $\begin{array}{c}\text { Number of response } \\
\text { received }\end{array}$ & 65 \\
\hline Response rate (\%) & $86.66 \%$ \\
\hline
\end{tabular}

\section{RESULT ANALYSIS}

The target population of the present study is restricted only to the experienced project managers client, and contractor. The questionnaire consist of 2 parts, the first part consist of demographic profile of engineers, second part covers variables relating to factors causing conflicts and disputes in the construction industry. The collected data were analyzed by using the SPSS 16. The total samples collected were 65 .

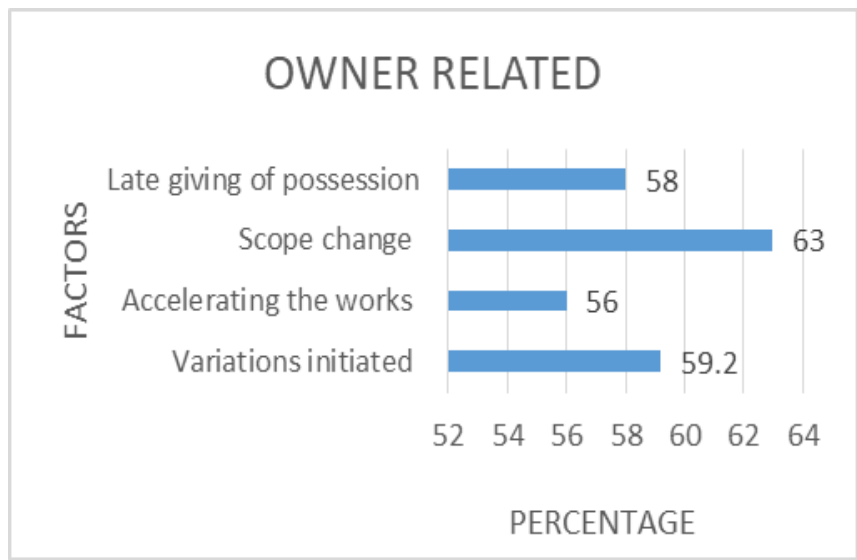

Fig 3. Owner related

$63 \%$ of the respondents feel that scope change made by the owner is the top owner related causes of conflicts and disputes in the construction industries.

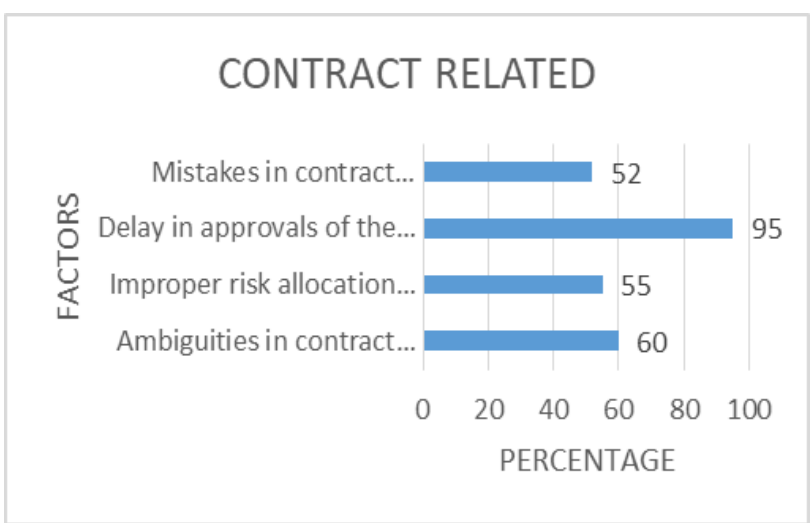

Fig 4. Contract related

95\% of the respondents feel that delay in approvals of the Contract is the top contract related causes of conflicts and disputes in the construction industries.

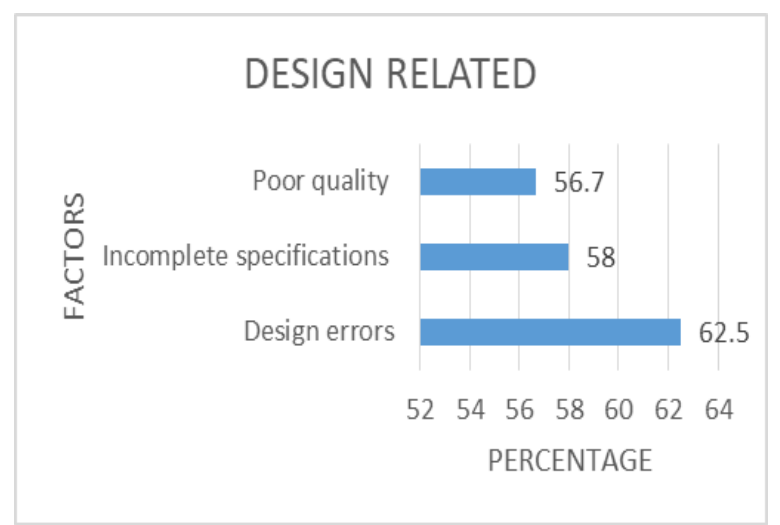

Fig 5. Design related

$62.5 \%$ of the respondents feel that disputes caused due to design errors is the top design related causes of conflicts and disputes in the construction industries.

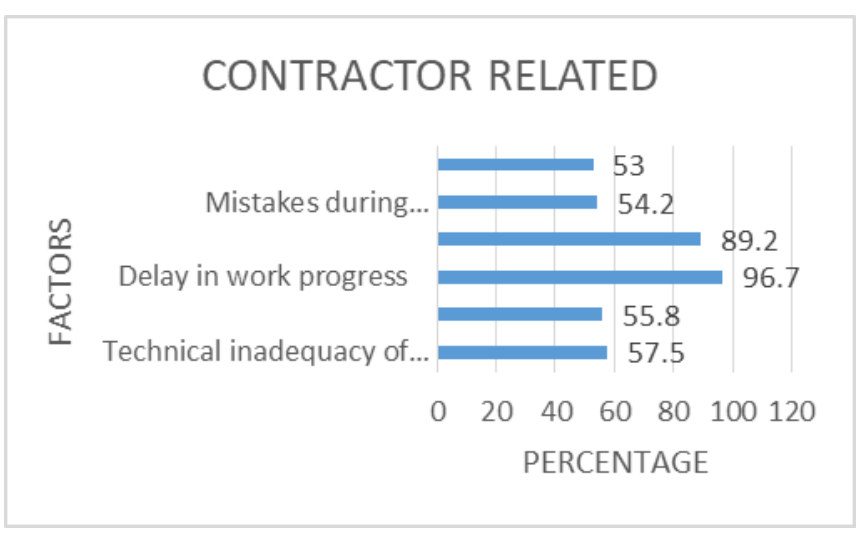

Fig .6 Contractor related

$96.7 \%$ of the respondents feel that delay in work progress by the contractor is the top contractor related causes of conflicts and disputes in the construction industries. 


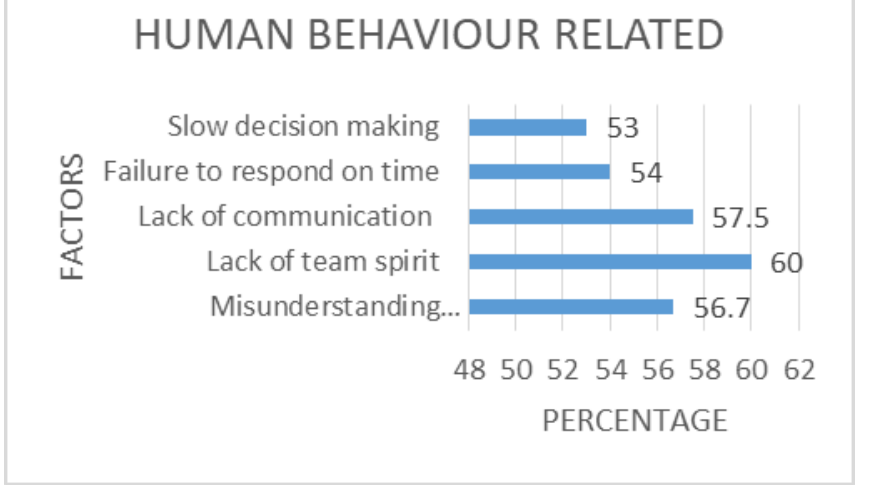

Fig 7. Human behaviour related

$60 \%$ of the respondents feel that lack of team spirit is the top human behaviour related causes of conflicts and disputes in the construction industries.

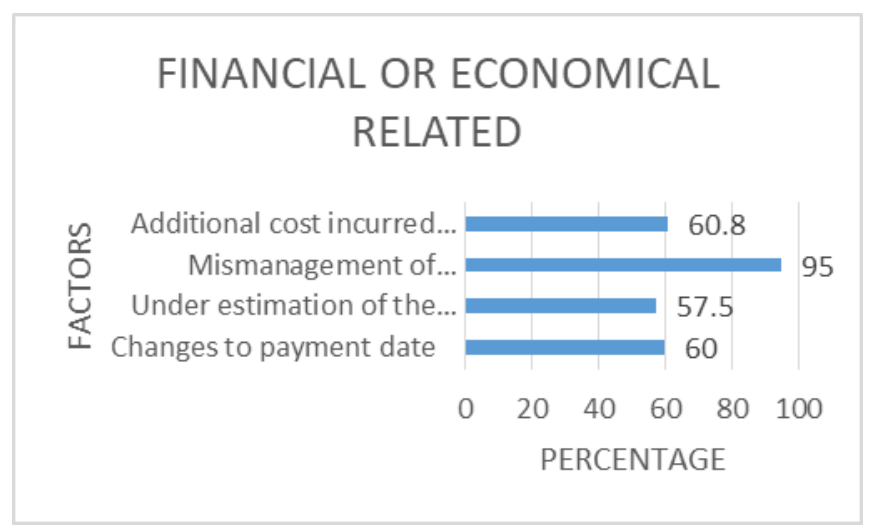

Fig 7. Financial or Economic related

$95 \%$ of the respondents feel that mismanagement of funds is the top financial or economic related causes of conflicts and disputes in the construction industries.

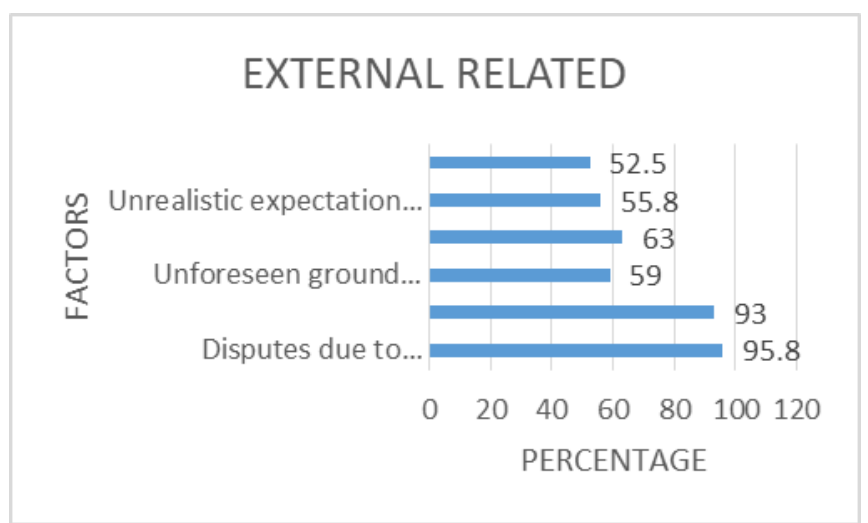

Fig 8. External related

$95.8 \%$ of the respondents feel that disputes due to uncertain accidents is the top external related causes of conflicts and disputes in the construction industries

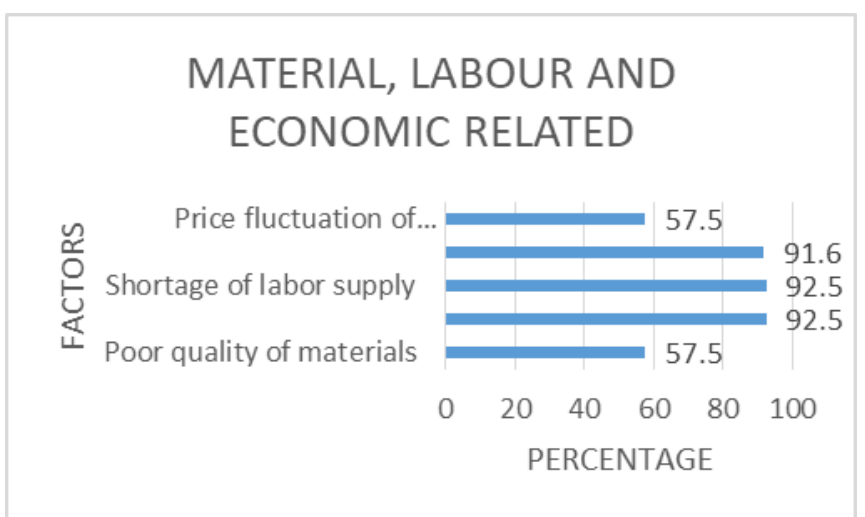

Fig 8. Material, Labour And Economic Related

92.5\% of the respondents feel that shortage of material and labor supply is the top material, labor and equipment related causes of conflicts and disputes in the construction industries.

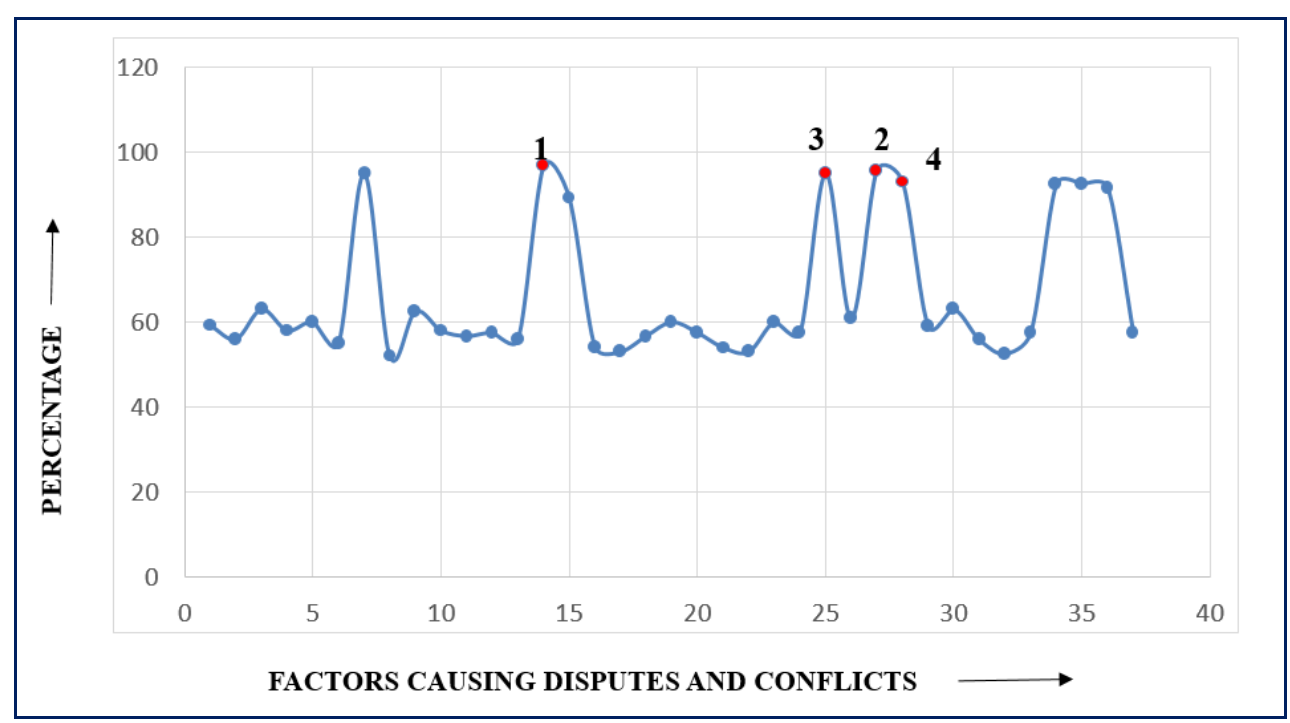

Fig 11. Overall graph 
Table No: 3. Descriptive Statistics for Factors

\begin{tabular}{|c|c|c|c|c|c|c|}
\hline S. No & Factors & Mean & Std. Deviation & Variance & RII & RANK \\
\hline 1 & Variations initiated by the owner. & 2.96 & .859 & .737 & 0.592 & 11 \\
\hline 2 & Accelerating the works for quick completion & 2.79 & .509 & .259 & 0.56 & 16 \\
\hline 3 & Scope change made by the owner & 3.16 & .565 & .319 & 0.63 & 7 \\
\hline 4 & Late giving of possession. & 2.91 & .584 & .341 & 0.58 & 13 \\
\hline 5 & Ambiguities in contract document. & 3.00 & .590 & .348 & 0.6 & 10 \\
\hline 6 & Improper risk allocation in contract. & 2.75 & .532 & .283 & 0.55 & 18 \\
\hline 7 & Delay in approvals of the contract. & 4.75 & .532 & .283 & 0.95 & 3 \\
\hline 8 & Mistakes in contract document & 2.58 & .775 & .601 & 0.52 & 23 \\
\hline 9 & Disputes caused due to design errors & 3.13 & 612 & .375 & 0.625 & 8 \\
\hline 10 & Incomplete specifications in design. & 2.92 & .654 & .428 & 0.58 & 13 \\
\hline 11 & Poor quality of design. & 2.83 & .761 & .580 & 0.567 & 15 \\
\hline 12 & Technical inadequacy of the contractor. & 2.87 & 612 & .375 & 0.575 & 14 \\
\hline 13 & Failure to plan and execute the change of work. & 2.79 & .884 & .781 & 0.558 & 17 \\
\hline 14 & Delay in work progress by the contractor & 4.83 & .482 & .232 & 0.967 & 1 \\
\hline 15 & Poor site management & 4.46 & .932 & .068 & 0.092 & 7 \\
\hline 16 & Mistakes during construction stage & 2.71 & .690 & .476 & 0.542 & 19 \\
\hline 17 & Lack of understanding and agreement in contract document. & 2.67 & .702 & .493 & 0.53 & 21 \\
\hline 18 & Misunderstanding between the parties & 2.83 & .381 & .145 & 0.567 & 15 \\
\hline 19 & Lack of team spirit. & 3.00 & .590 & .348 & 0.6 & 10 \\
\hline 20 & Lack of communication among team members. & 2.88 & .537 & .288 & 0.575 & 14 \\
\hline 21 & Failure to respond on time & 2.71 & 690 & .476 & 0.54 & 20 \\
\hline 22 & Slow decision making & 2.67 & 637 & .406 & 0.53 & 21 \\
\hline 23 & Changes to payment date. & 3.00 & .590 & .348 & 0.6 & 10 \\
\hline 24 & Under estimation of the project. & 2.88 & .537 & .288 & 0.575 & 14 \\
\hline 25 & Mismanagement of funds by contractor. & 4.75 & 608 & .370 & 0.95 & 3 \\
\hline 26 & Additional cost incurred as a result of rapidly increased prices. & 3.04 & .464 & .216 & 0.608 & 9 \\
\hline 27 & Disputes due to uncertain accidents & 4.79 & .415 & .172 & 0.958 & 2 \\
\hline 28 & Delay due to rework & 4.67 & .482 & .232 & 0.93 & 4 \\
\hline 29 & Unforeseen ground condition & 2.96 & .690 & .476 & 0.59 & 12 \\
\hline 30 & Poor record keeping & 3.17 & .816 & .667 & 0.63 & 7 \\
\hline 31 & Unrealistic expectation by the parties & 2.79 & .658 & .433 & 0.558 & 17 \\
\hline 32 & Extended work weeks & 2.63 & .924 & .853 & 0.525 & 22 \\
\hline 33 & Poor quality of materials & 2.88 & .797 & 636 & 0.575 & 14 \\
\hline 34 & Shortage of materials in market. & 4.63 & .495 & .245 & 0.925 & 5 \\
\hline 35 & Shortage of labor supply & 4.63 & .576 & .332 & 0.925 & 5 \\
\hline 36 & Equipment unavailability and failure & 4.58 & .504 & .254 & 0.916 & 6 \\
\hline 37 & Price fluctuation of construction material. & 2.88 & .338 & .114 & 0.575 & 14 \\
\hline
\end{tabular}

The Relative Importance Index (RII) was employed to rank the causes of conflicts and disputes in projects. The RII value was calculated with the following equation:

$$
R I I=\frac{\sum_{i=1}^{5} W i X i}{A X N}
$$

RII - Relative Importance Index.

$\mathrm{W}$ - Weighting given to each factor by the respondent and range from 1 to 5 .

$\mathrm{X}$ - Frequency of $\mathrm{i}^{\text {th }}$ response given for each factor.

A - Highest Weight.

$\mathrm{N}$ - Total number of respondents.

\section{CONCLUSION}

Conflicts and disputes is considered to perform a key role in an organization, which affects the successful completion of project to within a specific budget and within a certain period of time. It is very clear that conflicts and disputes in any construction will undergo cost overrun. This study "Identification of Causes of Conflicts and Disputes in Construction Company", provides a detailed investigation with their impact towards performance. 
Based on the analysis, the result shows that below factors were caused conflicts and disputes in Construction Industries

- Delay in work progress by the contractor $=96.7 \%$

- Disputes due to uncertain accidents $=95.8 \%$

- Delay in approvals of the contract $=95 \%$

- Mismanagement of funds by contractor $=95 \%$

- Delay due to rework=93\%

\section{REFERENCES}

1. Aryal S and Dahal R K (2018) "A Review of Causes and Effects of Dispute in the Construction Projects of Nepal", Journal of Steel Structure and Construction, Vol. 4, No.2, pp. 144-150.

2. Acharya N K (2006) "Conflicting factors in construction projects: Korean perspective", Engineering, Construction and Architectural Management, Vol. 13, No.6, pp. 543-566.

3. Bvumbwe C and Thwala D W (2011) An Exploratory Study of Dispute Resolution Methods in the South African Construction

4. Industry, International Conference on Information and Finance, Vol. 21, pp. 32-36.

5. Bhatt V (2001) "Avoidance of delay in resolution of disputes in construction contracts", National Conference on Commercial

6. Contracts and Construction Industry Arbitrations, Organised by The Indian Council of Arbitration, New Delhi, India, pp. 34-37.

7. Cakmak Emre and Pinar Irlayici Cakmak (2014) "An analysis of causes of disputes in the construction industry using analytical network process", Procedia-Social and Behavioral Sciences, Vol.109, pp.183-187.

8. Dangrochiya, Nency, Hiren Rathod, and Dr N D Sharma (2006) "A review on causes of disputes in construction industry", International journal of advanced research in engineering, science and management.

9. David B Lipsky and Henry S Farber (2016) "The Composition of Strike Activity in the Construction Industry", Industrial and Labor Relations Review, Vol. 29, No.3, pp. 388-404.

10. Heap-Yih Chong and Rosli Mohamad Zin (2012) "Selection of dispute resolution methods: factor analysis approach", Engineering, Construction and Architectural Management, Vol. 19, No.4, pp. 428-443

11. Iyer K C, Chaphalkar N B and Joshi G A (2008) "Understanding time delay disputes in construction industry", International Journal of Project Management, Vol. 26, pp.174-184.

12. Iyer K C (1996) "Identification and evaluation of dispute-prone clauses in Indian construction contracts", A Doctoral Thesis submitted at Indian Institute of Technology Madras, Chennai, India.

13. Joshi G A (2005) "Rule based expert system for contractual disputes pertaining to delays", An M.Tech. Thesis submitted at Indian Institute of Technology, Delhi, India.

14. Kathleen M J Harmon (2003) "Resolution of construction disputes: A review of current methodologies", Leadership and Management in Engineering, Vol. 3, pp. 187-201.

15. Kraiem Z M, Dagli Dhaval P, Diekmann J E (1989) "DISCON: an expert system for the analysis of differing site conditions claims", Knowledge Based System, Vol. 2, No,3, pp. 158-64.

16. Mohan M Kumaraswamy (1997) "Conflicts, claims and disputes in construction", Engineering, Construction and Architectural Management, Vol. 4, No.2, pp. 95-111.

17. Nirmal Kumar Acharya Young Dai Lee Hae Man Im (2006) "Conflicting factors in construction projects: Korean perspective", Engineering, Construction and Architectural Management, Vol. 13, No.6, pp. 543-566.

18. Panagiotis Mitropoulos and Gregory Howell (2001) "Model for understanding, preventing, and resolving project disputes", Journal of construction engineering and management, Vol. 127, pp. 223-231

19. Paula V. Prenzel and Frank Vanclay (2014) "How social impact assessment can contribute to conflict management", Environmental Impact Assessment Review, Vol. 45, pp. 30 -37.

20. Peter Love Peter Davis Joanne Ellis Sai On Cheung. (2010) Dispute causation: identification of pathogenic influences in construction. Engineering, Construction and Architectural Management, Vol. 17, No.4, pp. 404-423.

21. Rauzana Anita (2016) "Causes of conflicts and disputes in construction projects", Journal of mechanical and civil engineering, Vol.13, pp. $44-48$.
22. Randolph H. Thomas, Gary R. Smith and Dennis E. Wright (1990) "Resolving Disputes Over Contract notice Requirement", Journal of Construction Engineering and Management, Vol. 126, pp. 738-755.

23. Rizwan U. Farooqui, Fawwad Masood and Farhan Saleem. (2012) Key Causes of Construction Disputes in Pakistan, Advancing Civil, Architectural and Construction Engineering \& Management.

24. Shaikh S k Sameer, Dr Rajendra B Magar, Fauwaz Parkar (2016) Claims and Disputes in Construction Projects, International Journal for Research in Applied Science \& Engineering Technology, Vol. 13, No.5, pp. 44-48.

25. Sagar Soni, Mukesh Pandey and Sohit Agrawal (2017) "Conflicts and Disputes in Construction Projects: An Overview", International Journal of Engineering Research and Application, Vol. 7, No.6, pp. 40-42.

26. Sigitas Mitkus and Tomas Mitkus (2014) "Causes of conflicts in a construction industry: a communicational approach", Procedia - Social and Behavioral Sciences, Vol. 110, pp. 777-786.

27. Charlie Woodley (2019) "Will digitalisation end construction disputes?", Construction Research and Innovation.

28. Wantong Zhao (2019) "The root cause of claims and disputes in construction industry and solution analysis", Vol. 8, No.5, pp.1-18,

29. Wang C, Yap J B H, Wood, L C and Abdul-Rahman H (2019)."Knowledge modelling for contract disputes and change control", Production Planning and Control, Vol. 30. No.28, pp. 650-664.

\section{AUTHORS PROFILE}

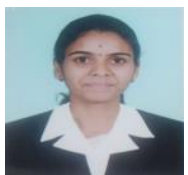

Ms.L.Madhumitha, pursuing M.E Construction Engineering and Management, Department of Civil Engineering, Kongu Engineering College, Erode, Tamilnadu, India. She can be reached at Email: madhulogu1996@gmail.com

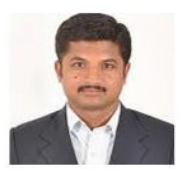

Mr.A.Sivakumar working as Assistant Professor in Kongu Engineering College, Erode, Tamilnadu in the stream of Civil Engineering. He published 8 international journals and 2 National journals. He is a life member in Indian Concrete Institute and International Association of Engineers. He can be reached at Email: sivakumarcivil36@gmail.com

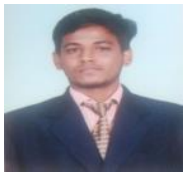

Mr.G.Dhanasekar, pursuing M.E Construction Engineering and Management, Department of Civil Engineering, Kongu Engineering College, Erode, Tamilnadu, India. He can be reached at Email: dhana7284.7@gmail.com

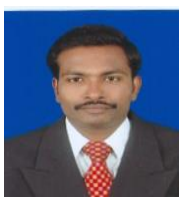

Dr.P.Karthikeyan working as Assistant Professor in Kongu Engineering College, Erode, Tamilnadu in the stream of department of Management Studies. He published 6 international journals and 10 National journals. He can be reached at Email: ptp_karthi@kongu.ac.in 